\title{
PROFIL TENAGA PENDIDIK LEMBAGA PENDIDIKAN ANAK USIA DINI (PAUD) KOTA PEKANBARU
}

\author{
Zaitun \\ Universitas Islam Negeri Sultan Syarif Kasim Riau, Indonesia \\ zaitun@uin-suska.ac.id
}

\begin{abstract}
Early age is a gold period for a child as to lay down his/her intelligence foundation, to develop, and to create the ability of cognitive, language, motoric, art, social, emotional, and behavior as well as religious value. The successes of these developments are strongly determined on how the quality of the surrounding where the child plays and the stimulant of the surrounding, one of them is PAUD (Early Age Education). Educators of PAUD take an important role to create conducive environment and to stimulate child's intelligence. As an educator in PAUD institution is not an easy job. There are many things that should be prepared in order that educational services in PAUD are suitable with all layers and bring the educator to be successful in developing PAUD in Indonesia, especially in Riau (Pekanbaru) under umbrella of $K_{3}$ program. Re-monitoring the profile of PAUD educators in all aspects is one of the ways to develop PAUD in the future.
\end{abstract}

\section{Pendahuluan}

Pendidikan Anak Usia Dini (PAUD) adalah suatu upaya pembinaan yang ditujukan kepada anak sejak lahir sampai dengan usia enam tahun yang dilakukan melalui pemberian rangsangan pendidikan untuk membantu pertumbuhan dan perkembangan jasmani dan rohani agar anak memiliki kesiapan dalam memasuki pendidikan lebih lanjut ( pasal 1, butir 14).

PAUD sebagai pendidikan yang diselenggarakan sebelum jenjang pendidikan dasar, memiliki kelompok sasaran anak usia o-6 tahun yang sering disebut sebagai masa emas perkembangan (golden age). Masa ini hanya terjadi satu kali dalam kehidupan manusia dan tidak dapat ditangguhkan pada priode berikutnya. Inilah yang menyebabkan masa anak sangat penting dalam kehidupan manusia.

Pendidikan bagi anak usia dini sangat penting dilakukan, sebab merupakan dasar bagi pembentukan kepribadian manusia secara utuh, yaitu ditandai dengan karakter, budi pekerti luhur, pandai, trampil. Serta menitikberatkan pada peletakan, dasar kearah pertumbuhan dan

${ }^{1}$ Direktorat Pendidikan Anak Usia Dini, Direktorat Jenderal Pendidikan Luar Sekolah dan Pemda, Konsep Dasar Pendidikan Anak Usia Dini, Departemen Pendidikan Nasional, Jakarta, 2004, Hlm 3 
perkembangan fisik (koordinasi motorik halus dan kasar, kecerdasan (daya fikir , daya cipta, kecerdasan emosi, kecerdasan spritual, sosio emosional (sikap dan prilaku serta agama, bahasa dan komunikasi sesuai dengan keunikan dan pertumbuhan anak usia dini disesuikan dengan tahap-tahap perkembangan yang dilaluinya. ${ }^{2}$ Usia o-6 tahun adalah usia yang paling kritis atau paling menentukan dalam pembentukan karakter dan kepribadian seseorang. Termasuk juga pengembangan intelegensi hampir seluruhnya terjadi pada usia tersebut.

Para tenaga pendidik, baik di lingkungan pendidikan anak usia dini secara formal maupun non formal perlu memberikan pendekatan pendidikan yang holistic, pendekatan ini merupakan salah-satu alternatif yang sesuai untuk mengembangkan kurikulum pendidikan agama. ${ }^{3}$ Pendekatan holistik dapat dilakukan dari diri pribadi seorang guru, yang mana seorang guru dalam mengajarkan materi pelajaran harus terlebih dahulu mensucikan hati, pikiran dan jiwanya, diiringi oleh niat ikhlas untuk menyampaikan ilmu pengetahuan bagi para siswa. Tidak dapat dipungkiri bahwa dengan modal niat ikhlas, suci hati, telah banyak terbukti bahwa dengan cara ini para siswa lebih mudah menangkap apa yang disampaikan oleh guru, lebih mudah menyerap ilmu pengetahuan dan mengaplikasikannya secara tepat. Demikian tentunya aplikasinya bagi dunia pendidikan anak usia dini.

Pendidik yang profesional dan mengetahui ilmu jiwa dan perkembangan anak usia dini sudah tentu mampu menerapkan konsepkonsep keilmuan yang selevel dengan pencernaan anak-anak usia dini, dan diharapkan mereka mampu merealisasikan potensi-potensi anak dalam mencapai cita-cita mereka.

Profesionalisme menyangkut mutu, kualitas dan tindak tanduk yang merupakan ciri suatu profesi atau orang yang profesional. ${ }^{4}$ Menurut Muchtar Luthfi yang dikutip Ahmad Tafsir, seseorang disebut memiliki profesi bila memenuhi kriteria: 1) profesi harus mengandung keahlian; 2) profesi dipilih karena panggilan hidup dan dijalani sepenuh waktu; 3) profesi memiliki teori-teori yang baku secara universal; 4) profesi adalah untuk masyarakat, bukan untuk diri sendiri; 5) profesi harus dilengkapi dengan kecakapan diagnostik dan kompetensi aplikatif; 6) pemegang profesi memiliki otonomi dalam melakukan tugas profesinya; 7) profesi

${ }^{2}$ Direktorat Pendidikan Anak Usia Dini, Direktorat Jenderal Pendidikan Luar Sekolah dan Pemda, Acuan Menu Pembelajaran pada Pendidikan Anak Usia Dini, Departemen Pendidikan Nasional, Jakarta, 2002, Hlm 1

3Ibnu Hadjar, "Pendekatan Holistik dalam Pendidikan Islam" dalam Paradigma Pendidikan Islam, Pustaka Pelajar, Yogyakarta, 2001, hlm. 125. Dapat pula dilihat dalam Abd. Rahman Abdullah, Aktualisasi Konsep Dasar Pendidikan Islam; Rekonstruksi Pemikiran dalam Tinjauan Filsafat Pendidikan Islam, UII Press, Yogyakarta, 2001

${ }^{4}$ Departemen Pendidikan dan Kebudayaan, Kamus Besar Bahasa Indonesia, Jakarta: Balai Pustaka, 1995, hlm. 789 
mempunyai kode etik, disebut kode etik profesi; 8) profesi harus mempunyai klien yang jelas, yaitu orang-orang yang membutuhkan layanan. ${ }^{5}$

Dalam pandangan E. Mulyasa, ada 5 prinsip yang dapat diterapkan kepala sekolah untuk mendorong tenaga kependidikan (guru) agar mau dan mampu meningkatkan profesionalitasnya, prinsip-prinsip tersebut ialah : 1 . Tenaga kependidikan akan bekerja lebih giat apabila kegiatan yang dilakukannya menarik dan menyenangkan; 2. Tujuan kegiatan perlu disusun dengan jelas dan diinformasikan kepada para tenaga kependidikan sehingga mereka mengetahui tujuan dia bekerja; 3. Para tenaga kependidikan harus selalu diberitahu tentang hasil dari setiap pekerjaanya; 4. Pemberian hadiah lebih baik daripada hukuman, namun sewaktu-waktu hukuman juga diperlukan; 5. Usahakan untuk memenuhi kebutuhan tenaga kependidikan dengan jalan memperhatikan kondisi fisiknya, memberikan rasa aman, menunjukkan bahwa kepala sekolah memperhatikan mereka, mengatur pengalaman sedemikian rupa sehingga setiap pegawai pernah memperoleh kepuasan dan penghargaan. ${ }^{6}$

Selanjutnya, dalam kerangka peningkatan profesionalisme guru, menurut Burn yang dikutip oleh Syafaruddin, kepala sekolah perlu memberdayakan para guru untuk berpartisipasi aktif, terbuka (transformatif), dan tanpa rasa takut dalam akhir proses menjaga dan mewujudkan visi sekolah serta budaya melalui diskusi aktif. ${ }^{7}$ Burn menjelaskan bahwa dasar kepemimpinan transformatif yaitu:

1. Partisipasi guru secara aktif dalam proses dinamis kepemimpinan dapat memberikan kontribusi pengetahuan, pemahaman, dan gagasan untuk membangun visi sekolah

2. Guru memperoleh rasa memiliki pribadi lebih baik dan kemudian komitmen pribadi terhadap nilai sekolah yang akan memelihara visi masa depan

3. Dengan keterlibatan pribadi secara aktif dalam poroses dan dengan tekad pribadi terhadap hasil, guru terdorong untuk berkembang dalam kesadaran akan misi luas sekolah dan hubungan mereka sehari-hari untuk bekerja kepada pencapaian misi. ${ }^{8}$

Sebagai gambaran perkembangan PAUD Non Formal dalam bentuk Kelompok Bermain (Play Group) di Kota Pekanbaru (Data Himpaudi Kota Pekanbaru Tahun 2008) adalah sebagai berikut:

${ }^{5}$ Ahmad Tafsir, Ilmu Pendidikan dalam Perspektif Islam, Bandung: Remaja Rosdakarya, 1991, hlm. 105

${ }^{6}$ E. Mulyasa, Menjadi Kepala Sekolah Profesional, Bandung: Remaja Rosdakarya, 2005, hlm. 121-122

${ }^{7}$ Syafaruddin, Efektivitas Kebijakan Pendidikan; Konsep, Strategi dan Aplikasi Kebijakan Menuju Organisasi Sekolah Efektif, Jakarta: Rineka Cipta, 2008, hlm. 140

${ }^{8}$ Robert G. Owens, Organizational Behavior in Education, London: Allyn and Bacon, 1995, hlm. 132 
Tabel 1. Data Himpaudi Kota Pekanbaru Tahun 2008

\begin{tabular}{|c|l|c|}
\hline NO & \multicolumn{1}{|c|}{ LOKASI/KECAMATAN } & $\begin{array}{c}\text { JUMLAH LEMBAGA PAUD } \\
\text { KELOMPOK BERMAIN }\end{array}$ \\
\hline $\mathbf{1}$ & Kec. Payung Sekaki & $\mathbf{1 7}$ \\
\hline $\mathbf{2}$ & Kec. Tampan & $\mathbf{3 0}$ \\
\hline 3 & Kec.Senapelan & $\mathbf{1 0}$ \\
\hline 4 & Kec.Marpoyan Damai & $\mathbf{1 9}$ \\
\hline 5 & Kec. Rumbai & 7 \\
\hline 6 & Kec. Rumbai Pesisir & 9 \\
\hline 7 & Kec.Sail & $\mathbf{1 1}$ \\
\hline 8 & Kec. Lima Puluh & 9 \\
\hline 9 & Kec. Kota Pekanbaru & $\mathbf{9}$ \\
\hline 10 & Kec. Bukit Raya & $\mathbf{1 1}$ \\
\hline $\mathbf{1 1}$ & Kec. Tenayan Raya & $\mathbf{1 3}$ \\
\hline $\mathbf{1 2}$ & Kec. Sukajadi & $\mathbf{1 6 2}$ \\
\hline & Jumlah & \\
\hline
\end{tabular}

Berdasarkan data jumlah lembaga PAUD Non Formal dalam bentuk Kelompok Bermain (play group) diatas, kiranya secara kuantitas perkembangan lembaga PAUD Non Formal relatif tinggi dan mengalami perkembangan yang pesat dan signifikan baik dapat jumlah peserta didik yang mengikuti mengalami pertumbuhan maupun dari segi kelembagaan PAUD sendiri, dimana akhir-akhirnya banyak lembaga PAUD yang berdiri dan menyelenggarakannya baik yang dikelola oleh organisasi kemasyarakatan maupun yayasan serta pemerintah. Artinya bahwa animo masyarakat cukup tinggi untuk memasukan anak mereka kelembaga PAUD Non Formal dalam bentuk Kelompok Bermain.

Perkembangan tersebut hendaknya juga diikuti dengan peningkatan kualitas (mutu) terutama dalam proses pembelajaran dan sumber daya manusia dalam hal ini pendidik PAUD itu sendiri. Dalam pembelajaran, salah satu komponen yang sangat mempengaruhi adalah pendekatan/strategi yang dilakukan pendidik. Terlihat bahwa pendidik lebih memilih menggunakan cara yang biasa yang berdasarkan pengalaman saja dan memiliki prinsip bukan mendidik akan tetapi mengasuh.

Pendidik anak usia dini adalah sosok individu yang memegang peranan penting dalam berbagai usaha yang terkait dengan pengemabangan program pendidikan anak usia dini. Anak usia dini adalah anak usia emas yang memiliki kepribadian yang unik. Kepribadian ini ditandai dengan ciri-ciri dan sifat bawaan serta latar belakang kehidupan yang berbeda-beda. Oleh karena itu guru atau pendidik anak usia dini perlu dipersiapkan untuk mampu menghadapi tantangan mendidik anak. 
Perkembangan yang pesat dirasakan bahwa, banyak lembaga PAUD berkembang dan bertumbuh dimana terutama di Pekanbaru. Namun suatu lembaga diminati masyarakat apabila dapat memenuhi tuntutan masyarakat terutama kesiapan tenaga pendidiknya. Jika tenaga pendidiknya profesional dan memliki kompetensi lainnya seperti kepribadian, sosial dan paedagogi tentu keinginan masyarakat akan terpenuhi. Profil pendidik demikian akan dapat menumbuhkan apresiasi positif masyarakat dan menumbuhkan motivasi orang tua memasukan anak ke lembaga PAUD.

Pertanyaan yang muncul adalah apakah pendidik PAUD yang ada sudah memenuhi keinginan masyarakat terutama dalam memberi pelayanan pendidikan anak usia dini. Mengingat dan melihat fenomena yang ada bahwa pendidik PAUD masih rendah kualitasnya dan menjadikan profesi ini sebagai the second profesion.

Hal ini mendorong penulis untuk meneliti tentang Profil Tanaga Pendidik pada lembaga Pendidikan Anak Usia Dini di kota Pekanbaru.

\section{Permasalahan}

Berdasarkan latar belakang masalah di atas, maka dapat dirumuskan permasalahan yang menjadi fokus dalam kajian dan penelitian ini, yaitu:

1. Bagaimanakah Profil tenaga pendidik lembaga PAUD khususnya di Kota Pekanbaru

2. Bagaimana usaha pemerintah dalam menyikapi persoalan tenaga pendidik PAUD tersebut

\section{Pembatasan dan Perumusan Masalah}

Melihat banyaknya masalah yang berkenaan dengan PAUD (Pendidikan Anak Usia Dini), serta terbatasnya kemampuan peneliti dari segi material maupun waktu maka peneliti membatasi ruang lingkup permasalahan pada Tenaga pendidik Pendidikan Anak Usia Dini (PAUD) pada jenis lembaga Non Formal Di kota Pekanbaru.

Adapun bentuk PAUD non formal tersebut, penulis batasi pada jenis kelompok bermain (play group) dan Taman Penitipan Anak (TPA) saja. Adapun rumusan masalah yang diteliti dalam penelitian ini dapat dirumuskan sebagai berikut :

1. Bagaimanakah Profil tenaga pendidik lembaga PAUD khususnya di Kota Pekanbaru

2. Bagaimana usaha pemerintah dalam menyikapi persoalan tenaga pendidik PAUD tersebut

\section{Tujuan dan Kegunaan Penelitian}

1. Tujuan Penelitian

Berdasarkan permasalahan di atas, maka tujuan penelitian ini adalah untuk mendapatkan gambaran tentang:

a. Profil tenaga pendidik pada lembaga PAUD khususnya kota Pekanbaru 
b. Upaya-upaya konkrit yang telah dilakukan pemerintah dalam menanganai pendidikan anak usia dini di kota Pekanbaru

2. Kegunaan Penelitian dapat dirumuskan ke dalam beberapa poin berikut:

a. Sebagai bahan informasi dan masukan bagi lembaga terkait khususnya pemerintah baik kementerian Pendidikan Nasional maupun Kementerian Agama, dan Perguruan Tinggi tentang mutu tenaga pendidik PAUD di kota Pekanbaru

b. Sebagai upaya pengembangan ilmu pengetahuan, khususnya bagi peneliti dan umumnya bagi masyarakat

\section{Landasan Teoritis}

Sesuai dengan ketentuan umum dalam Undang-Undang No.2o Tahun 2003 tentang sistem pendidikan Nasional Bab 1, bahwa pendidik adalah tenaga kependidikan yang berkualitas sebagai guru, dosen, pamong belajar, widyaswara, tutor, instruktur, fasilitator, dan sebutan lainnya sesuai dengan kekhususannya, serta berpartisipasi dalam menyelenggarakan pendidikan.

Guru memiliki kekhususan yang menjadi ciri kualitas dan profesi yang mengandung makna kesediaan seseorang untuk mengabdikan dirinya dalam suatu bidang pekerjaan mendidik. Sebagai profesi, guru :

1. Memposisikan diri sebagai pelayan, yang mengutamakan pelayanan sosial lebih dari pada keuntungan pribadi

2. Memiliki pengetahuan khusus, dalam hal ini pengetahuan mendidik anak usia dini

3. Memiliki kreativitas intelektual dalam rangka menjawab tantangan profesi yang dihadapi

4. Mendapat pengakuan dan status yang tinggi dari masyarakat

5. Memiliki otonomi yang tinggi yaitu kebebasan akademis di dalam mengungkapkan kemampuan diri dan bertanggungn jawab atas kemampuan dan kecakapannya.

Betapapun pendidikan anak usia dini sudah menjadi komitmen nasional, namun terwujud tidaknya komitmen tersebut sangat tergantung pada niat kita semua untuk tidak meninggalkan generasi yang lemah. Menjadi guru atau pendidik yang baik bagi anak usia dini adalah andil yang tidak ternilai pada pembangunan generasi penerus bangsa yang kita cintai.

Hal-hal yang harus dimiliki oleh pendidik PAUD:

1. Mempunyai ketakwaan yang tinggi kepada Tuhan YME

2. Mempunyai rasa sayang pada anak

3. Kejujuran yang tinggi

4. Konsisten dan komitmen yang tinggi

5. Murah senyum

6. Sabar

7. Tekun dan telaten 
8. Kreatif menggunakan bahan alam dan bahan sekitarnya untuk dijadikan media pembelajaran anak

9. Bekerja dengan sepenuh hati

10.Pandai menyanyi, mendongeng dan berkomunikasi dengan anak

11. Berfikir menurut apa di pikiran anak bukan apa yang ada di pikiran pendidik

12. Berkata menurut bahasa anak. ${ }^{9}$

Pekerjaan mendidik anak usia dini adalah pekerjaan yang mulia, yang tidak hanya bernilai ekonomi, tetapi lebih dari itu bernilai non ekonomi. Seorang pendidik PAUD merangsang terbentuknya rimbunan sel otak yang membentuk sirkuit otak anak. Waktu krisis tumbuh kembang otak berlangsung di usia dini. Selama o-6 tahun, pendidik PAUD merangsang terbentuknya kapasitas otak anak optimal dan maksimal. Setelah terbentuk, otak akan dipakai anak seumur hidupnya. Pendidik tidak hanya mendidik satu atau dua orang anak dalam setahun, bahkan bisa beratus anak jika pendidik telah mengajar bertahun-tahun.Berapa banyak anak telah dididik dan otak akan dipakai seumur hidup anak. Sebuah nilai non ekonomis yang sangat besar.

Pendidik PAUD akan membentuk karakter, jiwa, tata cara ibadah, dan menanamkan nilai positif bagi anak yang akan menjadi perilaku anak seumur hidup. Berapa banyak anak telah dididik dan prilaku tersebut telah menjadi kebiasaan anak seumur hidup anak, bukan hanya buat diri anak didik, tetapi juga pendidik, bahkan sebuah investasi tinggi bagi bangsa Indonesia yang sedang dalam krisis karakter.

\section{Metodologi Penelitian}

\section{Metode}

Metode penelitian yang digunakan dalam kegiatan penelitian ini adalah metode penelitian deskriptif kualitatif. Penelitian kualitatif karena kegiatan ini ingin mendapatkan pengalaman yang lebih jelas dan mendalam tentang berbagai kasus atau fenomena yang ditemui. Data yang digunakan menggunakan data kualitatif, maksudnya data disajikan sebagian besar dalam bentuk verbal, dan tidak berbentuk numerik. (Noeng Muhadjir, 2002, hal. 46).

Populasi dalam penelitian ini berjumlah 162 lembaga dengan jumlah pendidik PAUD Non Formal 486 orang. Sedangkan pengambilan sample peneliti menggunakan tekhnik sampling. Untuk menentukan sample yang akan digunakan dalam penelitian ini maka peneliti meetapkan tekhnik Purposive Random Sampling. Dimana sample yang ada dalam populasi dilakukan secara acak dengan pertimbangan

${ }^{9}$ Netti Herawati, Buku pendidik pendidikan anak usia dini, Quantum, Pekanbaru, 2005, Hlm.18 
tertentu ${ }^{10}$ yang ada dalam populasi. Dalam hal ini peneliti hanya menentukan pendidik yang berada pada 3 ( Tiga ) kecamatan yaitu kecamatan Sukajadi, Tampan dan Bukit Raya.

\section{Alat Pengumpulan data}

Alat pengumpulan data dalam penelitian ini adalah, interview ,dokumentasi, observasi partisipan dan didukung oleh quisioner. Interview dilakukan kepada pendidik, kepala sekolah. Observasi untuk melihat aktivitas kelas yang terkait dengan kualitas pendidik PAUD Non formal. Selain itu, observasi juga meliputi ketersediaan ragam sarana dan prasarana (APE) Sementara quisioner juga diperuntukkan kepada pendidik PAUD di Kota Pekanbaru.

\section{Tekhnik Analisa Data}

Seluruh data yang diperoleh dianalisis secara deskriptif kualitatif. Penafsiran dan analisis dilakukan setelah semua data diklasifikasi menurut kesamaan gejalanya dan dikoding menurut masing-masing kategori. Kemudian semua data yang relevan dengan variable penelitian dan dihubungkan satu sama lain sehingga dapat ditarik kesimpulan yang menggambarkan profil pendidik PAUD di Kota Pekanbaru.

\section{Langkah-Langkah Penelitian}

Langkah-langkah penelitian yang ditempuh adlah:pertama; melakukan pendataan jumlah lembaga PAUD beserta jumlah pendidik yang sebenarnya di setiap kecamatan di Kota Pekanbaru, sehingga diketahui jumlah keseluruhan pendidiknya yang ada. Kedua; melakukan penetapan sampel berdasarkan kriteria yang telah ditentukan. Ketiga; melakukan pengumpulan data disetiap lembaga PAUD terutama yang terkait dengan pendidik dan aspek-aspeknya. Keempat; melakukan klasifikasi, koding dan penafsiran data. kelima; melakukan analisis secara lebih tajam terhadap temuan-temuan penelitian.

\section{Lokasi}

Sasaran kegiatan ini adalah pendidik PAUD Non formal dalam yang ada di Kota Pekanbaru yang berdomisili pada kecamatan Sukajadi, Tampan dan Bukit Raya.

\section{Pembahasan Hasil/ Temuan Penelitian}

1. Deskripsi Data tentang profil tenaga pendidik PAUD di Kota Pekanbaru

Dalam kajian ini, peneliti berhasil menjaring data mengenai profil pendidik PAUD sebanyak 221 orang, yang terdiri dari 8o orang pendidik kecamatan Sukajadi, 98 orang pendidik PAUD kecanatan Tampan, dan 43 kecamatan Bukit Raya. Selanjutnya data-data tersebut dkalsifikasikan berdasarkan sejumlah karakteristik yang merupakan penjabaran dari profil tenaga pendidik PAUD Non formal di Kota Pekanbaru.

1o Prof.Dr.Sugiyono, Metode Penelitian Pendidikan (Pendekatan Kuantitatif, Kualitatif, dan $R \mathcal{E} D$ ), Alfabeta, Bandung, 2008, Hlm 124 
a. Distribusi Tenaga Pendidik Menurut Jenis kelamin

Responden yang merupakan tenaga pendidik, ternyata diominasi oleh perempuan dan tidak berimbang antara jumlah perempuan dan laki-laki yang bersedia menjadi pendidik PAUD, seperti yang terlihat pada tabel berikut:

Tabel 2. Distribusi Tenaga Pendidik Menurut Jenis kelamin

\begin{tabular}{|c|c|c|c|}
\hline NO & Jenis Kelamin & Frekwensi & Prosentase \\
\hline 1 & Perempuan & 211 & $95,47 \%$ \\
\hline 2 & Laki-laki & 10 & $0,45 \%$ \\
\hline & Jumlah & $\mathbf{2 2 1}$ & $\mathbf{1 0 0}$ \\
\hline
\end{tabular}

Tabel 2 di atas menunujukkan bahwa dari 211 ( 95,47\%) tenaga pendidik PAUD yang berada pada 3 ( tiga ) kecamatan ternyata mayoritas responden adalah perempuan. Hal tersebut didukung oleh wawancara peneliti dengan salah seorang kepala sekolah PAUD, beliau mengatakan bahwa minat yang paling tinggi untuk menjadi pendidik PAUD adalah perempuan karena perempuan lebih sabar dan telaten dalam mendidik anak usia o-6 tahun tersebut. ${ }^{11}$

b. Distribusi Tenaga Pendidik Menurut Latar Belakang Pendidikan

Dalam hal ini, latar belakang pendidikan tenaga PAUD non formal di kota Pekanbaru dibagi ke dalam berbagai kategori yaitu SLTA/Sederajat, Diploma Satu (D1), Diploma Dua (D2), Diploma Tiga (D3), Strata Satu (S1) dan Strata Dua (S2)

Tabel 3. Distribusi Tenaga Pendidik Menurut Latar Belakang

Pendidikan

\begin{tabular}{|c|c|c|c|}
\hline No & $\begin{array}{c}\text { Latar Belakang } \\
\text { Pendidikan }\end{array}$ & Frekwensi & Prosentase \\
\hline 1 & SLTA & 120 & $54,29 \%$ \\
\hline 2 & $\mathrm{D}_{1}$ & 6 & $0,27 \%$ \\
\hline 3 & $\mathrm{D}_{2}$ & 32 & $1,44 \%$ \\
\hline 4 & $\mathrm{D}_{3}$ & 17 & $0,76 \%$ \\
\hline 5 & $\mathrm{~S}_{1}$ & 44 & $\mathbf{1 , 9 9} \%$ \\
\hline 6 & $\mathrm{~S} 2$ & 2 & 0,09 \\
\hline & Jumlah & $\mathbf{2 2 1}$ & $\mathbf{1 0 0}$ \\
\hline
\end{tabular}

Tabel di atas, jelas terlihat bahwa latar belakang pendidikan tenaga pendidik PAUD masih mayoritas adalah sekolah lanjutan tingkat atas baik itu SMA, SMEA, SMK, SPG dan Madrasah Aliyah.mencapai 120 orang ( 54,29\%), diikuti oleh Tenaga Pendidik yang telah menyelesaikan Strata Satu sebanyak 44 orang ( $1,99 \%)$. Dengan berbagai disiplin keilmuan, ada yang Sarjana Psikologi,

${ }^{11}$ Umi Sa'adah, Wawancara, Kepala Sekolah Rabithatul Ulum, Tanggal 17 Juli 2010 
Ekonomi, Sı PAUD, Fisipol, Sarjana Agama, Sarjana hukum. Kemudian strata dua (S2) berjumlah 2 orang ( o,09 \%).Inilah yang menjadi persoalan, bahwa pendidik PAUD yang ada secara mayoritas belum memenuhi kualifikasi pendidik profesional karena kompetensi paedagogik belum mamenuhi sebagaimana dalam UU Guru dan Dosen bahwa pendidik pada pendidikan anak usia dini harus memiliki kualifikasi akademik $\mathrm{D}_{4}$ atau $\mathrm{S}{ }^{12}$

c. Distribusi Tenaga Pendidik Menurut Pengalaman Mengajar

Pengalaman mengajar, merupakan komponen yang harus didapatkan informasinya melalui responden, karena pengalaman mengajar pendidik akan mengambarkan keantusiasan dan keseriusan menjalankan fungsi sebagai pendidik, lebih jelas lihat tabel 4 berikut:

Tabel 4. Distribusi Tenaga Pendidik Menurut Pengalaman

\section{Mengajar}

\begin{tabular}{|c|c|c|c|}
\hline No & Lama/Tahun & Frekwensi & Prosentase \\
\hline 1 & 9 Tahun & 4 & 0,018 \\
\hline 2 & 8 Tahun & 1 & 0,045 \\
\hline 3 & 7 Tahun & 2 & 0,090 \\
\hline 4 & 6 Tahun & 10 & 0,452 \\
\hline 5 & 5 Tahun & 7 & 0,316 \\
\hline 6 & 4 Tahun & 31 & $\mathbf{1 , 4 0 2}$ \\
\hline 7 & 3 Tahun & 89 & 4,027 \\
\hline 8 & 2 Tahun & 47 & 2,126 \\
\hline 9 & 1 Tahun & 25 & $\mathbf{1 , 1 1 3}$ \\
\hline 10 & $<1$ tahun & 5 & 0,226 \\
\hline & Jumlah & 221 & 100 \\
\hline
\end{tabular}

Tabel di atas menunjukkan bahwa respon yang memiliki pengalaman mengajar mencapai 9 tahun hanya 4 orang (o,018\%), suatu hal sangat mustahil karena mengingat lembaga PAUD telah lama ada. Kemudian responden yang mayoritas pengalaman mengajarnya hanya 3 tahun sebanyak 89 orang ( 4,027 \%). Beberapa wawancara sempat peneliti lakukan untuk melacak informasi tentang minimnya pengalaman mengajar pendidik PAUD, terungkap bahwa tenaga pendidik yang mengajar di lembaga PAUD ternyata hanya menjadikan lembaga PAUD sebagai batu loncatan saja untuk mendapatkan tempat mengajar atau pekerjaan yang sesuai dengan keilmuannya. Setelah mereka mendapat berbagai pelatihan dan bekal wawasan, para pendidiknya dengan tanpa beban meninggalkan lembaga yang telah membesarkannya. ${ }^{13}$

\footnotetext{
${ }^{12}$ Diah Masriah, Wawancara, Ketua Himpaudi Kecamatan Sukajadi, 20 Juli 2010

${ }^{13}$ Dinawati, Wawancara, pengelola PAUD, tanggal 20 Juli 2010
} 
d. Distribusi Data Pendidik Menurut Usia

Pengungkapan data tentang tahun lahirnya tenaga pendidik PAUD, akan mempertimbangkan bagaimana kondisi emosional dan psikologis responden. Tabel berikut akan memaparkan kondisi yang dimaksud:

Tabel 5. Data Pendidik Menurut Usia

\begin{tabular}{|c|c|c|c|}
\hline No & Usia & Frekwensi & Prosentase \\
\hline 1 & $>40$ tahun & 42 & 19,00 \\
\hline 2 & $>30$ tahun & 62 & 28,05 \\
\hline 3 & $>20$ tahun & 117 & 52,94 \\
\hline & Jumlah & 221 & 100 \\
\hline
\end{tabular}

Tabel 5 menunjukkan bahwa dari 221 responden penelitian ini hamper tiga perempat yang berusia muda, 117 orang $(52,49 \%)$. Tenaga pendidik PAUD usianya sangat produktif ( usia kerja) dan hanya sebagian kecil yang berusia diatas 40 tahun.

e. Distribusi Data Tentang Pelatihan Yang Pernah Diikuti Tenaga Pendidik PAUD

Tabel 6. Data Tentang Pelatihan Yang Pernah Diikuti Tenaga Pendidik PAUD

\begin{tabular}{|c|c|c|c|}
\hline No & Jawaban & Frekwensi & Prosentase \\
\hline 1 & $\begin{array}{l}\text { Mengikuti } \quad \text { Pelatihan } \\
\text { PAUD }\end{array}$ & 46 & 2,081 \\
\hline 2 & $\begin{array}{l}\text { Tidak mengikuti } \\
\text { Pelatihan PAUD }\end{array}$ & 175 & 79,18 \\
\hline & Jumlah & 221 & 100 \\
\hline
\end{tabular}

Tabel 6 mengungkapkan bahwa kesempatan mengikuti pelatihan tentang PAUD baik menyangkut metode BCCT, ESQ, TOT PAUD, Workshop, pelatihan aritmatika, Metode qiroati, pengajaran bahasa Inggeris ke anak, mendongeng, sempoa dan pelatihan peningkatan kompetensi guru PAUD lainnya sangat minim dilakukan oleh tenaga pendidik PAUD, ada pendidik yang lebih menyenangi mengasuh anak titipan TPA nya daripada diutus mengikuti pelatihan pendidik PAUD.

2. Deskripsi tentang usaha pemerintah dalam menyikapi persoalan tenaga pendidik PAUD Kota Pekanbaru

Berdasarkan wawancara yang peneliti lakukan kepada beberapa lembaga yang pernah melakukan MoU antarakementerian Pendidkian nasional dengan 4 (empat) organisasi perempuan yaitu PKK, BKOW, Muslimat NU dan Aisyiah. Diperoleh informasi bahwa kemeterian pendidikan Nasional sudah melakukan berbagai hal sepserti melakukan 
akreditasi lembaga PAUD yang ada, lomba lemabag PAUD, lomba pendidik PAUD berprestasi baik tingkat daerah maupun provinsi, jambore pendidik PAUD, mengadakan berbagai pelatihan pembinaan profesionalisme pendidik PAUD secara bertahap ${ }^{14}$, meberikan intensif berupa transpor dan bantuan hari raya atau THR.

\section{Pembahasan}

Dengan memperhatikan tabel 2 di atas, menunjukkan bahwa tenaga pendidik PAUD jika dilihat dari jenis kelamin, mayoritas responden menjawab berjenis kelamin perempuan (95, 47 \%). Dengan demikian peminat paling besar untuk tenaga pendidik PAUD diminati oleh perempuan. Hal tersebut dikarenakan oleh pendidik PAUD hendaklah individu yang lemah lembut, sabar, keibuan, penyayang dan memperlakukan siswa seperti anak sendiri.

Kemudian pada tabel 3, latar belakang pendidikan tenaga pendidik PAUD, berada pada tingkat SLTA ( 54, $29 \%$ ), kemudian S1 (1,99\%). Perbandingan yang tidak seimbang, dimana tenaga pendidik PAUD masih berpendidikan SLTA. Hal ini didasarkan karena Para pengelola PAUD non formal seperti kelompok bermain dan Taman Penitipan Anak belum secara seragam memberlakukan syarat menjadi guru PAUD adalah bersrata satu (S1). Hal tersebut juga berkaitan dengan jumlah gaji yang mereka peroleh serta ketidak sanggupan pengelola PAUD membayar gaji yang layak ditenggarai menjadi penyebab mengapa mayoritas tenaga pendidik berpendidikan SLTA.

Demikian juga halnya dengan pengalaman mengajar tenaga pendidik PAUD, mayoritas responden menyampaikan bahwa pengalaman mengajar mereka hanya 3 tahun $(4,027 \%)$ dan 2 tahun $(2,126 \%)$. Tentu dapat dibayangkan pengalaman mengajar yang minim ditambah lagi gaji yang tidak sesuai, pendidikan yang tidak memadai tentu kualitas pembelajaran menjadi rendah. Menjadi pendidik PAUD tidak hanya sekedar memiliki pengetahuan saja akan tetapi dibutuhkan skill tambahan untuk menghadapi keunikan siswa yang beragam.

Tabel 5 kemudian menggambarkan usia pendidik PAUD berada pada usia yang relatif muda $>20$ tahun mencapai angka 117 orang (52,95 \%). Sebenarnya usia ini saangat potensial untuk dikembangkan. Untuk itu beberapa lembaga PAUD meminta kepada pendidik mereka untuk melanjutkan pendidikan ke jenjang $\mathrm{D}_{1}, \mathrm{D}_{2}, \mathrm{D}_{3}$ dan $\mathrm{S}_{1}$ PAUD.

Adapun pelatihan yang pernah diikuti oleh pendidik PAUD, pada tabel 6 tergambar bahwa 175 orang $(79,18 \%)$ tenaga pendidik PAUD belum mengikuti pelatihan baik pelatihan BCCT, ESQ, TOT PAUD, dan lain sebagainya. Menurut beberapa pengakuan guru, bahwa pelatihan yang diselenggarakan tidak merata serta penunjukkan juga tiak jelas,

14 Supni. Wawancara, Staf PLS/PT Kementerian Pendidikan Nasional provinsi Riau, tanggal 7 September 2010 
sehingga ada lembaga PAUD yang selalu diundang mengikuti pelatihan dan ada yang tidak pernah mengikuti pelatihan sama sekali.

\section{Penutup}

1. Kesimpulan berikut:

Berdasarkan hasil penelitian di atas, dapat disimpulkan sebagai

a. Profil tenaga pendidik PAUD non formal di Kota Pekanbaru dapat dikategorikan cukup memuaskan

b. latar belakang pendidikan tenaga pendidik tersebut masih perlu ditingkatkan lagi, sesuai dengan UU no 14 tahun 2005 tentang guru dan dosen. Para pendidik PAUD ini juga berhak disertifikasi seperti halnya guru pada tingkat TK, SD, SLTA dan SLTA

c. Peluang untuk mengembangkan diri menjadi lebih optimal karena tenaga pendidik PAUD berada pada usia produktif

d. Perlu pemerataan kesempatan mengikuti pelatihan pengembangan diri khusus bagi tenaga pendidik PAUD

2. Rekomendasi

Beberapa hal yang perlu menjadi pemikiran semua pihak terkait, diantaranya:

a. Bagi masyarakat, terutama pihak yang konsen dengan pendidikan anak usia dini merupakan tanggung jawab bersama untuk mensuport pendidik PAUD agar tetap bersemangat, dan memiliki motivasi untuk melakukan yang terbaik dalam menjalankan tugasnya

b. Bagi pengelola PAUD, baik yayasan maupun organisasi, perlu memberikan dukungan moril dan materiil terhadap tenaga pendidik PAUD

c. Kemendiknas, sebagai payung hendaknya bisa menjadi wadah yang senantiasa memberikan angin segar kepada tenaga pendidik ini dengan cara memasukan dana insentif bagi pendidik PAUD dalam APBD maupun APBN 


\section{DAFTAR KEPUSTAKAAN}

Ibnu Hadjar, "Pendekatan Holistik dalam Pendidikan Islam" dalam Paradigma Pendidikan Islam, Pustaka Pelajar, Yogyakarta, 2001, Dapat pula dilihat dalam Abd. Rahman Abdullah, Aktualisasi Konsep Dasar Pendidikan Islam; Rekonstruksi Pemikiran dalam Tinjauan Filsafat Pendidikan Islam, UII Press, Yogyakarta, 2001

Departemen Pendidikan dan Kebudayaan, Kamus Besar Bahasa Indonesia, Jakarta: Balai Pustaka,

Ahmad Tafsir, Ilmu Pendidikan dalam Perspektif Islam, Bandung: Remaja Rosdakarya, 1991,

E. Mulyasa, Menjadi Kepala Sekolah Profesional, Bandung: Remaja Rosdakarya, 2005

Syafaruddin, Efektivitas Kebijakan Pendidikan; Konsep, Strategi dan Aplikasi Kebijakan Menuju Organisasi Sekolah Efektif, Jakarta: Rineka Cipta, 2008

Robert G. Owens, Organizational Behavior in Education, London: Allyn and Bacon, 1995,

Abdurrahman al-Nahlawi, Ushul al-Tarbiyyah wa Asalibuha fi al-Bayt wa alMadrasah wa al-Mujtama', Dar al-Fikr, Damaskus, 1979

Abd. Halim Soebahar, Wawasan Pendidikan Islam, Kalam Mulia, Jakarta, 2002

Abd. Rahman Abdullah, Aktualisasi Konsep Dasar Pendidikan Islam; Rekonstruksi Pemikiran dalam Tinjauan Filsafat Pendidikan Islam, UII Press, Yogyakarta, 2001

Burhan Nurgiantoro, Dasar-dasar Pengembangan Kurikulum Sekolah; Sebuah Pengantar Teoretis dan Pelaksanaan, BPEE, Yogyakarta, 1988

Crow and Crow, Pengantar Ilmu Pendidikan, Rakesarasin, Yogyakarta, 1990, Edisi III

Departemen Pendidikan Nasional, Beyond enters and Circles Time (BCCT); Pendekatan Sentra dan Saat Lingkaran dalam Pendidikan Anak Usia Dini, Direktorat Jenderal Pendidikan Luar Sekolah Direktorat Pendidikan Anak Usia Dini, Jakarta, 2006

Departemen Pendidikan Nasional, Pedoman Blockgrant Rintisan Program Pendidikan Anak Usia Dini Non-Formal, Direktorat Jenderal Pendidikan Luar Sekolah Direktorat Pendidikan Anak Usia Dini, Jakarta, 2007

Direktorat Pendidikan Anak Dini Usia, Direktorat Jenderal Pendidikan Luar Sekolah, Konsep Dasar Pendidikan Anak Usia Dini, Direktorat Pendidikan Anak Usia Dini, Jakarta, 2004

Farid Esack, Al-Qur'an, Liberalisme, Pluralisme Membebaskan yang Tertindas, Mizan, Bandung, 1997 
Ibnu Hadjar, "Pendekatan Holistik dalam Pendidikan Islam” dalam Paradigma Pendidikan Islam, Pustaka Pelajar, Yogyakarta, 2001

John P. Miller, Humanizing The Class-Room, Penyadur Abdul Munir Mulkhan, Kreasi Wacana Yogya, Yogyakarta, 2002

Jujun S. Suriasumantri, Filsafat Ilmu; Sebuah Pengantar Populer, Pustaka Sinar Harapan, Jakarta, 1999

Louay Safi, The Foundation of Knowledge; a Comparative Study in Islamic and Western Methods of Inquiry, International Institute of Islamic Thought, Kuala Lumpur, 1996

Popper, "The Defence of Rationalisme" Selection, David Miller (Ed.), Princeton, New Jersey, 1985

Sumadi Suryabrata, Metodologi Penelitian, Raja Gtafindo Persada, Jakarta, 1983

Wahjo Sumidjo, Kepemimpinan Kepala Sekolah; Tinjauan Teoretik dan Permasalahannya, Raja Grafindo Persada, Jakarta, 2005

Yayasan Pendidikan Muslimat NU Bina Bakti Wanita Pusat (YPMNU), Kurikulum PAUD Formal dan Non Formal, Direktorat Jenderal Pendidikan Islam Direktorat Pendidikan Madrasah bekerja sama dengan YPMNU, Jakarta, 2007

Sugiyono, Metode Penelitian Pendidikan (Pendekatan Kuantitatif, Kualitatif, dan R \& D), Alfabeta, Bandung, 2008. 